\title{
Scenarios of major terrestrial ecosystems in China
}

\author{
Tian Xiang Yue ${ }^{a, *}$, Ze Meng Fan ${ }^{b}$, Ji Yuan Liu ${ }^{a}$, Bo Xin $\mathrm{Wei}^{\mathrm{c}}$ \\ a State Key Laboratory of Resources and Environment Information System, Institute of Geographical Sciences and Natural Resources \\ Research, Chinese Academy of Sciences, 100101 Beijing, China \\ $\mathrm{b}$ Research Center for Eco-Environmental Sciences, Chinese Academy of Sciences, 100085 Beijing, China \\ c Beijing K \& G Consultants Ltd, 100029 Beijing, China
}

\section{A R T I C L E I N F O}

Article history:

Published on line 25 July 2006

Keywords:

Holdridge Life Zones

Scenarios

Mean-center shift

Spatial pattern

HadCM2

HadCM3

\begin{abstract}
A B S T R A C T
The spatial pattern and mean-center shift of major terrestrial ecosystems, termed Holdridge Life Zones (HLZ), during the periods from 1961 to 1990 (T1), from 2010 to 2039 (T2), from 2040 to 2069 (T3) and from 2070 to 2099 (T4) were analyzed by combining the zonal patterns of climatic change in China and the climatic change scenarios of HadCM2 and HadCM3. The results showed that nival area would decrease rapidly with temperature increase in the future. HadCM2 and HadCM3 predicted that the nival areas might disappear in 552 years and 204 years, respectively. Using both HadCM2 and HadCM3, the five HLZ types with the largest areal extent are nival zone, cool temperate moist forest, warm temperate moist forest, subtropical moist forest and boreal wet forest, which collectively account for more than $50 \%$ of China's land mass. Among these five HLZ types, nival zone, warm temperate moist forest and boreal wet forest would decrease continuously, whereas subtropical moist forest and cool temperate forest would increase continuously during the four periods. HLZ diversity and patch connectivity would increase continuously in the 21st century. The shift distances of mean centers of HLZ types simulated using HadCM3 were markedly greater than those simulated using HadCM2, in general. The results from both HadCM2 and HadCM3 showed that boreal wet forest, subtropical moist forest, tropical dry forest, warm temperate moist forest and subtropical wet forest had bigger shift ranges, indicating that these HLZ types are more sensitive to the climatic change scenarios of HadCM2 and HadCM3.
\end{abstract}

(c) 2006 Elsevier B.V. All rights reserved.

\section{Introduction}

The spatial pattern of major terrestrial ecosystems in China and the associated pattern of change in the four decades from the 1960s to the 1990s were analyzed by using the Holdridge Life Zone (HLZ) model with daily temperature and precipitation data since 1960, selected from 735 weather stations scattered across China (Yue et al., 2005). The results showed that the HLZ spatial pattern in China changed substantially during the four decades. For instance, the nival zone showed a rapid decrease, indicating that it might disappear in 159 years, if it were to keep shrinking at the average rate observed dur- ing the four decades. Alpine dry tundra and cool temperate scrub increased continuously over the four decades, giving decadal increase rates of $13.1 \%$ and $3.4 \%$, respectively. HLZ patch connectivity exhibited a continuous pattern of increase, and HLZ diversity a continuous pattern of decrease (Yue et al., 2001, 2005). The warm temperate thorn steppe, subtropical wet forest and cool temperate wet forest shifted by $1781.45 \mathrm{~km}$, $1208.14 \mathrm{~km}$ and $977.43 \mathrm{~km}$, respectively, over the four decades. These HLZ types were more sensitive to climate change than the others.

In this paper, scenarios of major terrestrial ecosystems in China during the periods 2010-2039 (T2), 2040-2069 (T3) and

\footnotetext{
* Corresponding author. Tel.: +8610 64889633; fax: +861064889630. E-mail address: yue@LREIS.ac.cn (T.X. Yue). 
2070-2099 (T4) were simulated by combining zonal patterns of climatic change in China (Yue et al., 2005) with the climatic change scenarios of HadCM2 and HadCM3.

HadCM2 and HadCM3 were developed at the Hadley Centre for Climate Prediction and Research in the United Kingdom on the basis of greenhouse gas and sulfate aerosol forcing experiments. HadCM2 was differentiated into HadCM2GG and HadCM2GS. HadCM2GG uses the combined forcing of all the greenhouse gases as an equivalent $\mathrm{CO}_{2}$ concentration. HadCM2GS uses the combined equivalent $\mathrm{CO}_{2}$ concentration plus the negative forcing from sulfate aerosols. HadCM2GS results suggested that global warming could accelerate as greenhouse gas forcing begins to dominate over sulfate aerosol forcing (Mitchell et al., 1995). Both the ocean and atmospheric components of the HadCM2 model employ a spatial horizontal grid point spacing of $3.75^{\circ}$ longitude (about $400 \mathrm{~km}$ ) and $2.5^{\circ}$ latitude (about $280 \mathrm{~km}$ ). The atmosphere model and the ocean model use 19 and 20 vertical levels, respectively (Giorgi, 2002). Compared to HadCM2, HadCM3 includes an enhanced land surface scheme that tends to improve the mid-latitude summer surface climatology (Cox et al., 1999). HadCM3 uses the same horizontal atmospheric and land surface grid as HadCM2. The ocean component of HadCM3 does not require flux adjustments (Collins et al., 2001; Johns et al., 2003), and it is run at a higher horizontal resolution $\left(1.25^{\circ} \times 1.25^{\circ}\right)$

\section{Methods}

\subsection{HLZ classification}

The Holdridge Life Zone (HLZ) classification is a scheme that uses three bioclimatic variables derived from standard meteorological data to formulate the relationship between climate patterns and broad-scale vegetation distribution. It relates the distribution of major ecosystems (termed "life zones") to the bioclimatic variables. The HLZ classification divides the world into over 100 life zones on the basis of mean annual biotemperature (MAB) in degrees centigrade, average total annual precipitation (TAP) in millimeters and potential evapotranspiration ratio (PER) logarithmically. Biotemperature is defined as the mean of unit-period temperatures with substitution of zero for all unit-period values below $0{ }^{\circ} \mathrm{C}$ and above $30^{\circ} \mathrm{C}$ (Holdridge et al., 1971). Evapotranspiration is the total amount of water that is returned directly to the atmosphere in the form of vapor through the combined processes of evaporation and transpiration. Potential evapotranspiration is the amount of water that would be transpired under constantly optimal conditions of soil moisture and plant cover. The potential evapotranspiration ratio is the ratio of mean annual potential evapotranspiration to average total annual precipitation, which provides an index of biological humidity conditions. In other words, MAB, TAP and PER at site $(x, y)$ and in the th year have the following formulation:

$\operatorname{MAB}(x, y, t)=\frac{1}{365} \sum_{j=1}^{365} \operatorname{TEM}(j, x, y, t)$
$\operatorname{TAP}(x, y, t)=\sum_{j=1}^{365} P(j, x, y, t)$

$\operatorname{PER}(x, y, t)=\frac{58.93 \mathrm{MAB}(x, y, t)}{\operatorname{TAP}(x, y, t)}$

where $\operatorname{TEM}(j, x, y, t)$ is the value obtained by summing the hourly temperatures above $0^{\circ} \mathrm{C}$ and below $30^{\circ} \mathrm{C}$ on the jth day and dividing by $24 ; P(j, x, y, t)$ is precipitation on the $j$ th day.

Suppose

$M(x, y, t)=\ln \operatorname{MAB}(x, y, t)$

$T(x, y, t)=\ln \operatorname{TAP}(x, y, t)$

$P(x, y, t)=\ln \operatorname{PER}(x, y, t)$

$d_{i}(x, y, t)=\sqrt{\begin{array}{l}\left(M(x, y, t)-M_{i 0}\right)^{2}+\left(T(x, y, t)-T_{i 0}\right)^{2} \\ +\left(P(x, y, t)-P_{i 0}\right)^{2}\end{array}}$

where $M_{i 0}, T_{i 0}$ and $P_{i 0}$ are standards of MAB logarithm, TAP logarithm and PER logarithm at the central point of the ith life zone in the hexagonal system of HLZs. When $d_{k}(x, y, t)=$ $\min _{i}\left\{d_{i}(x, y, t)\right\}$, the site $(x, y)$ is classified as the kth life zone.

\subsection{Models related to spatial pattern}

On the basis of HLZ classification, the mean-center model, the ecological diversity index and the patch connectivity index are employed to analyze spatial pattern scenarios of major ecosystems in China. The mean-center model is formulated as (Yue et al., 2005),

$x_{j}(t)=\sum_{i=1}^{I_{j}} \frac{S_{i j}(t) \cdot X_{i j}(t)}{S_{j}(t)}$

$y_{j}(t)=\sum_{i=1}^{I_{j}} \frac{S_{i j}(t) \cdot Y_{i j}(t)}{S_{j}(t)}$

where $t$ is the variable of time; $I_{j}(t)$ the patch number of HLZ type $j$; $s_{i j}(t)$ the area of the ith patch of HLZ type $j$; $S_{j}(t)$ the total area of HLZ type $j ;\left(X_{i j}(t), Y_{i j}(t)\right)$ the longitude and latitude coordinates of the geometric center of the ith patch of HLZ type $j$; and $\left(x_{j}(t), y_{j}(t)\right)$ is the mean center of HLZ type $j$.

Shift distance and direction of HLZ $j$ in the period from $t$ to $t+1$ are, respectively, formulated as,

$D_{j}=\sqrt{\left(x_{j}(t+1)-x_{j}(t)\right)^{2}+\left(y_{j}(t+1)-y_{j}(t)\right)^{2}}$

$\theta_{j}=\operatorname{arctg}\left(\frac{y_{j}(t+1)-y_{j}(t)}{x_{j}(t+1)-x_{j}(t)}\right)$

where $D_{j}$ is the shift distance of HLZ type $j$ in the period from $t$ to $t+1 ; t=1,2$ and 3 , respectively, represent $\mathrm{T} 1$ (the period from 1961 to 1990), T2 (the period from 2010 to 2039) and T3 
(the period from 2040 to 2069); $\theta_{j}$ the shift direction of HLZ type $j$, with due east being $0^{\circ}$, due north $90^{\circ}$, due west $180^{\circ}$ and due south $270^{\circ} ;\left(x_{j}(t), y_{j}(t)\right)$ and $\left(x_{j}(t+1), y_{j}(t+1)\right)$ are, respectively, the coordinates of the mean center of HLZ type $j$ in the years $t$ and $t+1$. When $0^{\circ}<\theta_{j}<90^{\circ}$, HLZ type $j$ shifts towards the northeast during the period from $t$ to $t+1$; when $90^{\circ}<\theta_{j}<180^{\circ}$, HLZ type $j$ shifts towards the northwest; when $180^{\circ}<\theta<270^{\circ}$, HLZ type $j$ shifts towards the southwest; when $270^{\circ}<\theta<360^{\circ} \mathrm{HLZ}$ type $j$ shifts towards the southeast.

The ecological diversity index is expressed as (Yue et al., 2003, 2001, 1998),

$d(t)=-\frac{\ln \left(\sum_{i=1}^{m(\varepsilon)}\left(p_{i}(t)\right)^{1 / 2}\right)^{2}}{\ln (\varepsilon)}$

where $t$ is the variable of time; $p_{i}(t)$ the probability of the ith ecotope; $m(\varepsilon)$ the total number of investigation objects; $\varepsilon=1 / e+a$, where $a$ is the area of the region studied in hectares and e equals 2.71828 .

The patch connectivity index is formulated as (Yue et al., 2003, 2004),

$\mathrm{CO}(\mathrm{t})=\sum_{i=1}^{m(t)} \sum_{j=1}^{n_{i}(t)} p_{i j}(t) \cdot S_{i j}(t)$ where $p_{i j}$ is proportion of the area of the $j$ th patch in the ith type to the total area under investigation; $t$ the variable of time; $S_{i j}(t)$ the index of movement efficiency of migrants or propagules in the patch $(i, j) ; 0 \leq C(t) \leq 1.1$; and when all patches have the shape of a hexagon, $C(t)=1.0$.

\subsection{Simulation process}

The data used in the HadCM2 and HadCM3 global change models were downloaded from the IPCC Data Distribution Centre (http://ipcc-ddc.cru.uea.ac.uk) and consist of mean monthly data for the four periods, T1, T2, T3 and T4. Data processing included the following steps: (1) matching coordinates to each datum of the downloaded data; (2) converting mean monthly data into mean annual data, transforming the data format into a text file using Visual $\mathrm{C}++(\mathrm{VC}++)$; (3) transforming the mean annual data into point coverage with the AML/ArcInfo program; (4) operating the improved gradientplus-inverse distance squared (GIDS) model in ArcObjects with VBA control and creating mean annual biotemperature surfaces for the four periods on the basis of digital elevation model and point coverage of mean annual biotemperature; (5) operating the improved GIDS model in ArcObjects with VBA control and creating mean annual biotemperature surfaces on the basis of digital elevation model and point coverage of mean annual biotemperature; (6) creating mean annual precipitation surfaces by kriging interpolation and transform-

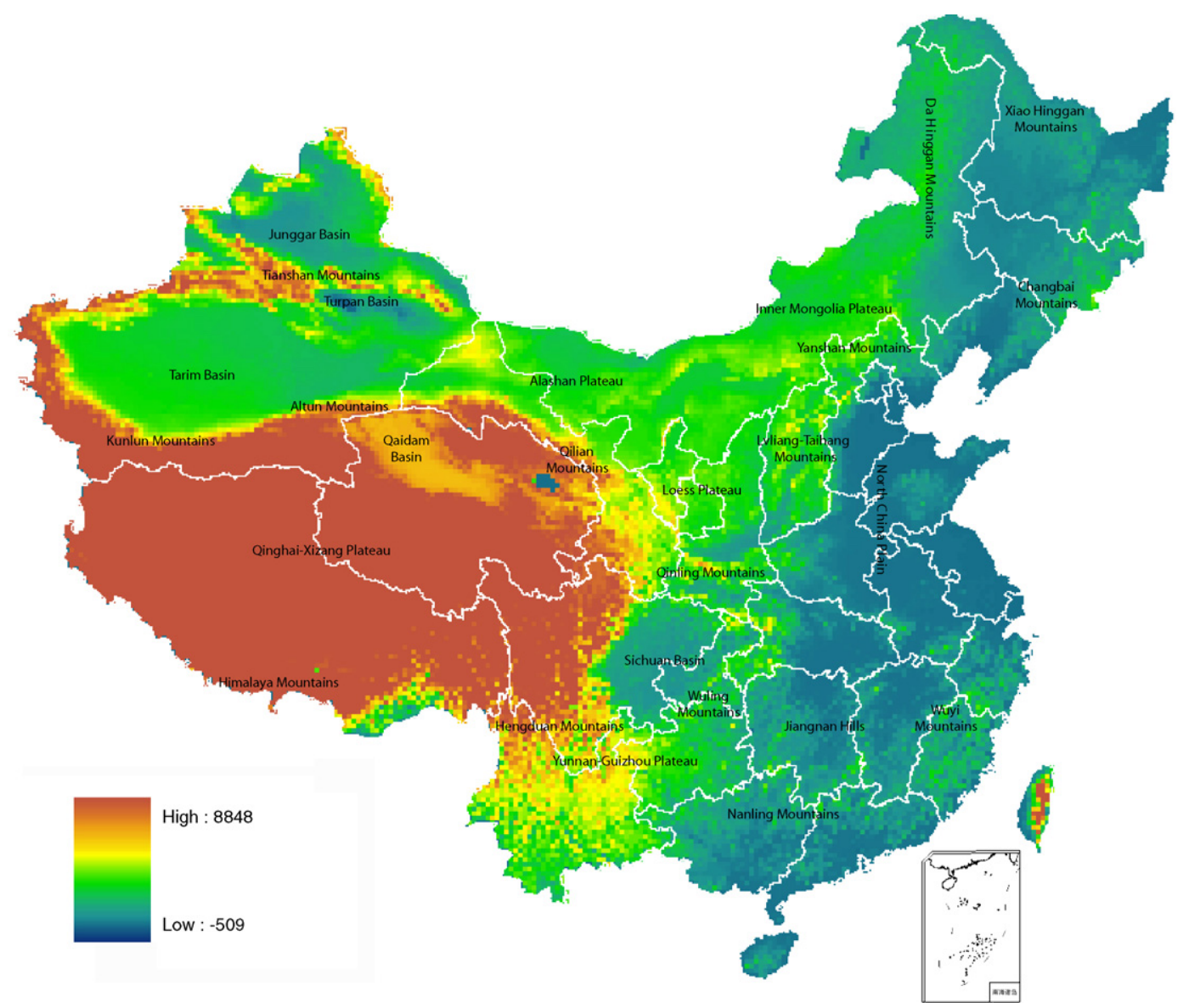

Fig. 1 - Digital elevation model of China. 
Table 1 - Linear relationships between the decrease in temperature $(T)$ with increase in elevation (E) in different regions of China (Yue et al., 2005)

\begin{tabular}{|c|c|c|c|}
\hline Regions & $\begin{array}{l}\text { Correlation } \\
\text { coefficients }\end{array}$ & $\begin{array}{l}\text { Decreasing rate } \\
\left({ }^{\circ} \mathrm{C} / \mathrm{m}\right)\end{array}$ & Linear regression equation \\
\hline Changbai Mountains & -0.96 & 0.0028 & $\mathrm{~T}=-0.0028 \mathrm{E}+9.3481$ \\
\hline Da Hinggan and Xiao Hinggan mountains & -0.84 & 0.0040 & $\mathrm{~T}=-0.0040 \mathrm{E}+8.3638$ \\
\hline Qinghai-Xizang Plateau & -0.95 & 0.0029 & $\mathrm{~T}=-0.0029 \mathrm{E}+14.442$ \\
\hline Hengduan Mountains & -0.95 & 0.0054 & $\mathrm{~T}=-0.0054 \mathrm{E}+24.542$ \\
\hline Loess Plateau & -0.87 & 0.0036 & $T=-0.0036 E+14.111$ \\
\hline Nanling Mountains & -0.90 & 0.0060 & $T=-0.0060 E+18.996$ \\
\hline Qilian Mountains & -0.99 & 0.0037 & $\mathrm{~T}=-0.0037 \mathrm{E}+14.787$ \\
\hline Qinling Mountains & -0.76 & 0.0040 & $T=-0.0040 E+15.681$ \\
\hline Taihang and Lvliang mountains & -0.97 & 0.0050 & $T=-0.0050 E+14.53$ \\
\hline Tianshan Mountains & -0.85 & 0.0038 & $T=-0.0038 E+13.858$ \\
\hline Wuling Mountains & -0.94 & 0.0055 & $\mathrm{~T}=-0.0055 \mathrm{E}+18.112$ \\
\hline Wuyi Mountains & -0.90 & 0.0044 & $T=-0.0044 E+18.848$ \\
\hline Himalaya Mountains & -0.85 & 0.0064 & $T=-0.0064 E+30.978$ \\
\hline Yanshan Mountains & -0.98 & 0.0046 & $\mathrm{~T}=-0.0046 \mathrm{E}+12.258$ \\
\hline Yunnan-Guizhou Plateau & -0.85 & 0.0045 & $T=-0.0046 E+19.979$ \\
\hline
\end{tabular}
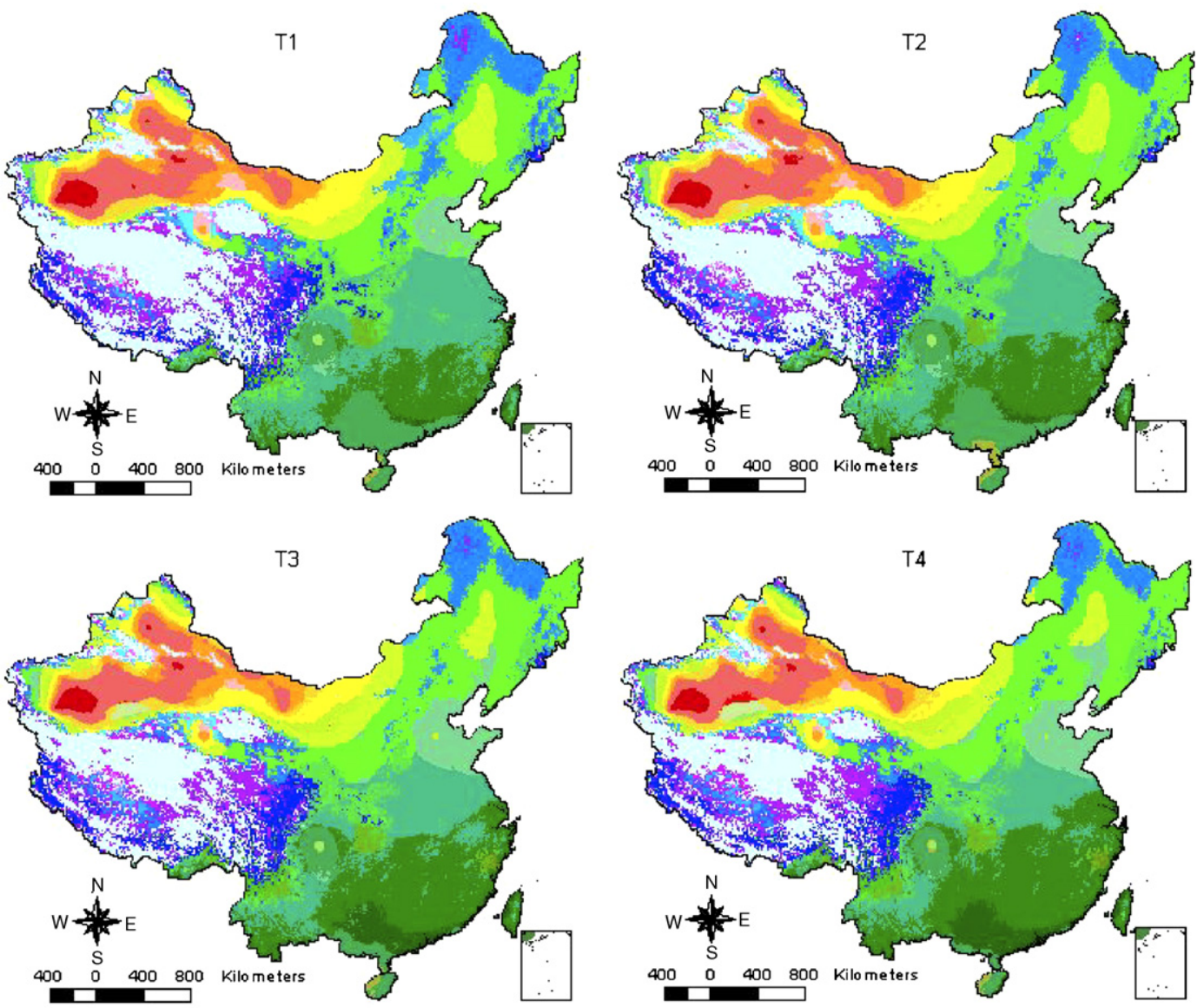

Legend

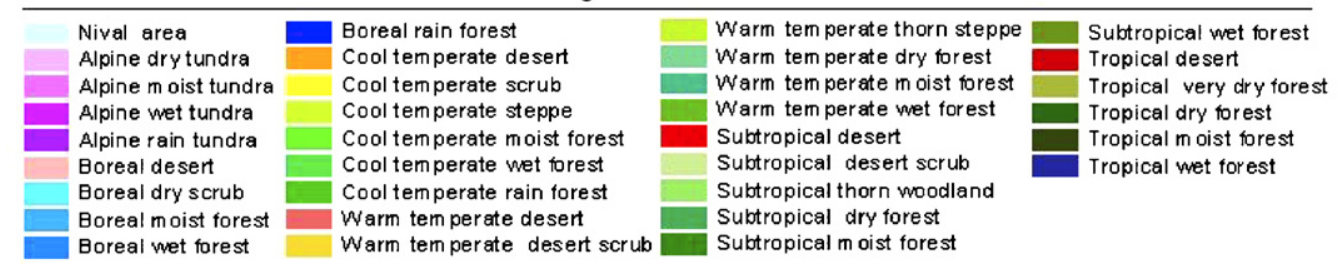

Fig. 2 - Holdridge Life Zone spatial distribution predicted by HadCM2 for the periods 1961-1990 (T1), 2010-2039 (T2), 2040-2069 (T3) and 2070-2099 (T4). 
ing the point coverage into 1-km grid data using the Spatial Analyst module of ArcInfo; (7) converting the 1-km grid data into ASCII data with the ArcToolbox module and ArcInfo/AML; (8) calculating potential evapotranspiration in ASCII data by using modular programming of $\mathrm{VC}++$ and then transforming the results into grid data; (9) conducting grid computation of biotemperature, precipitation and evapotranspiration; (10) operating the HLZ model with the ASCII data using VC++; (11) transforming the ASCII data from the HLZ model into 1-km grid data and then converting the $1-\mathrm{km}$ grid data into polygon coverage.

We should note that there is a significant negative correlation between temperature and elevation in China. The multivariate regression model of the relationship between temperature $T$, longitude $X$, latitude $Y$ and elevation $E$ gave $T=43.312-0.106 \mathrm{X}-0.469 \mathrm{Y}-0.00361 \mathrm{E}$, with a correlation coefficient of -0.98 (Yue et al., 2005). Primary temperature sur- faces were created using the improved GIDS model, which was specifically formulated as,

$T_{j k}=\sum_{i=1}^{N_{j k}} \frac{\begin{array}{c}2 T_{i}-\left[0.0046 \cdot\left(E_{j k}-E_{i}\right)+0.106 \cdot\left(X_{j k}-X_{i}\right)\right. \\ \left.+0.469 \cdot\left(Y_{j k}-Y_{i}\right)+0.0036 \cdot\left(E_{j k}-E_{i}\right)\right]\end{array}}{2 d_{i j k}^{2}\left(\sum_{i=1}^{N_{j k}} d_{i j k}^{-2}\right)}$

Then, the primary temperature surfaces were corrected using a $1 \mathrm{~km} \times 1 \mathrm{~km}$ digital elevation model of China (Fig. 1) and relationships between temperature and elevation (Table 1). Because there was no statistically significant correlation between precipitation and elevation, the kriging interpolation method was selected to create $1 \mathrm{~km} \times 1 \mathrm{~km}$ precipitation surfaces, providing a higher accuracy than the Inverse Distance Weighted method (Yue and Du, 2005).
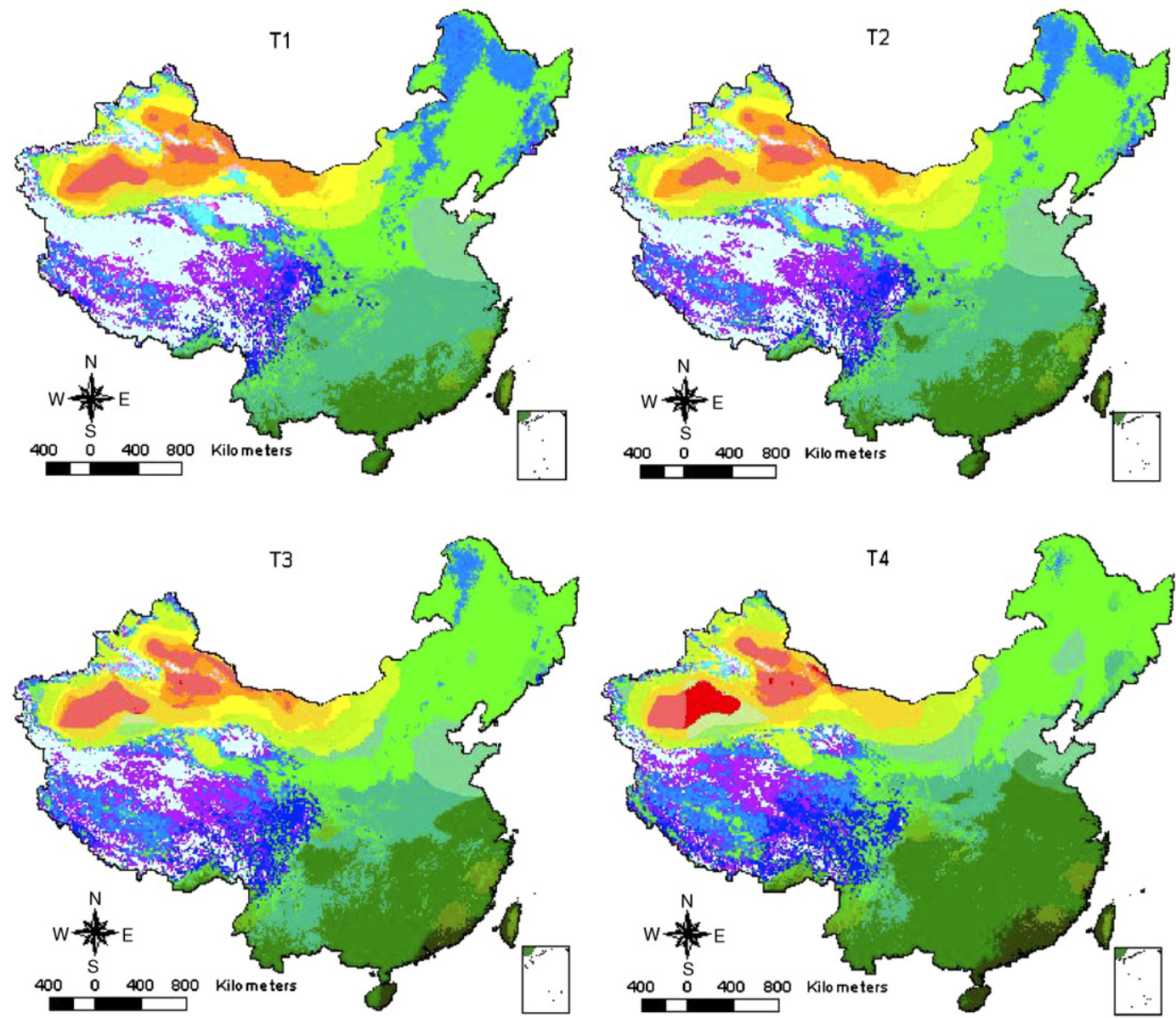

Legend

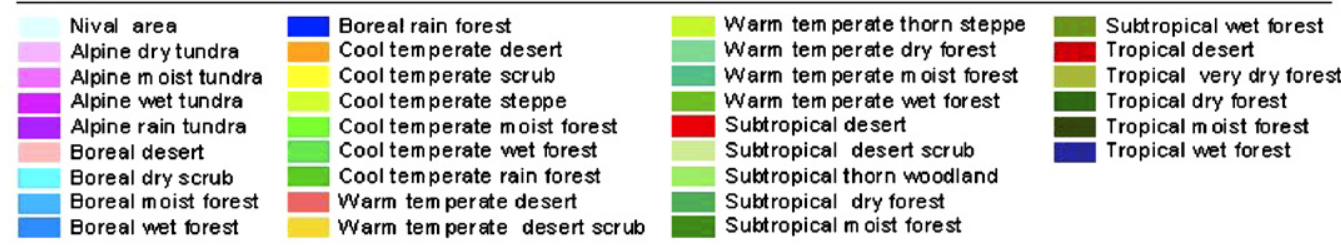

Fig. 3 - Holdridge Life Zone spatial distribution predicted by HadCM3 for the periods 1961-1990 (T1), 2010-2039 (T2), 2040-2069 (T3) and 2070-2099 (T4). 


\section{Results}

\subsection{HLZ spatial distribution}

According to HadCM2, there would be 30 HLZ types in T1. Subtropical desert scrub would appear in the northern part of lower Altun Mountains in T2, subtropical desert in the eastern Tarim Basin in T3 and tropical wet forest in the archipelagoes of the South China Sea in T4 (Fig. 2). HadCM3 generated 28 HLZ types in T1 (Fig. 3). Tropical dry forest would appear in the southwestern Yunnan and the southwestern Hainan in T2. In T3, subtropical desert would appear in the eastern Tarim Basin and would have a rapid expansion trend; subtropical thorn woodland would appear in the northern part of the lower Altun Mountains. Subtropical desert scrub would appear in the area between the subtropical desert and the subtropical thorn woodland arising in T3. Subtropical dry forest would be distributed in southwestern Yunnan in $\mathrm{T} 1$, which would disappear in $\mathrm{T} 2$ and $\mathrm{T} 3$, and would reappear in the Taishan Mountain area of the North China Plain in $\mathrm{T} 4$.

In general, HadCM2 and HadCM3 created a similar HLZ spatial distribution pattern in the 21st century (Figs. 2 and 3).
Nival area, alpine dry tundra and alpine moist tundra would be distributed mainly in the Qinghai-Xizang Plateau and in the Tianshan and Qilian high mountains. Alpine wet tundra and alpine rain tundra would appear around the nival area, the alpine dry and alpine moist tundra as well as the northern mountaintops of the Da Hingan Mountains. The boreal desert would occur in the Beishan Mountain area of the northern Qinghai-Xizang Plateau, Tarim Basin and north of Turpan Basin. The tropical desert would appear in the central areas of the Tarim, Turpan and Junggar basins. The warm temperate desert would be located around the tropical desert, while the inner cool temperate desert would be distributed mainly in the middle of the Alashan Plateau and Junggar Basin. Cool temperate scrub, warm temperate desert scrub and subtropical desert scrub would be found on the margins of the northern Qinghai-Xizang Plateau, the western Tarim Basin, the western and northeastern Junggar Basin as well as the southeastern Alashan Plateau and the southwestern Inner Mongolian Plateau. Boreal dry scrub would be present mainly in low mountain areas of the Qinghai-Xizang Plateau, and the Tianshan and Qilian mountains. Cool temperate steppe would be found mainly in the Mongolian and Loess Plateau regions and southwest of Northeast Plain. The warm temperate thorn steppe would appear in the southeast of Himalaya

Table 2 - Holdridge Life Zone mean-center shift predicted by HadCM2

\begin{tabular}{|c|c|c|c|c|c|c|c|}
\hline \multirow[t]{2}{*}{ Code } & \multirow[t]{2}{*}{ HLZ type (name) } & \multicolumn{2}{|c|}{ From T1 to T2 } & \multicolumn{2}{|c|}{ From $\mathrm{T} 2$ to $\mathrm{T} 3$} & \multicolumn{2}{|c|}{ From T3 to T4 } \\
\hline & & Distance (km) & Direction & Distance (km) & Direction & Distance (km) & Direction \\
\hline 1 & Nival & 21.3724 & Southwest & 9.2447 & Northwest & 6.0281 & Southeast \\
\hline 2 & Alpine dry tundra & 42.0014 & Southwest & 157.6814 & Northwest & 27.5054 & Southwest \\
\hline 3 & Alpine moist tundra & 53.9373 & Northwest & 173.6284 & Northeast & 151.3185 & Northeast \\
\hline 4 & Alpine wet tundra & 20.4538 & Southwest & 59.7608 & South & 11.2154 & Southwest \\
\hline 5 & Alpine rain tundra & 138.1902 & Southwest & 32.9498 & Northwest & 35.0088 & West \\
\hline 6 & Boreal desert & 44.0795 & Northwest & 61.4476 & Northeast & 29.7994 & Northwest \\
\hline 7 & Boreal dry scrub & 21.6816 & Northwest & 85.6761 & Northwest & 40.4330 & Northwest \\
\hline 8 & Boreal moist forest & 639.6778 & Southwest & 310.7023 & Southwest & 208.5016 & Southwest \\
\hline 9 & Boreal wet forest & 226.2427 & Southwest & 90.8159 & Northwest & 174.1970 & Southwest \\
\hline 10 & Boreal rain forest & 58.2990 & Northwest & 95.4113 & Southwest & 50.1217 & Southwest \\
\hline 11 & Cool temperate desert & 97.9508 & Southwest & 46.6987 & Northeast & 125.2279 & Northeast \\
\hline 12 & Cool temperate scrub & 55.1869 & Northwest & 72.9184 & Northwest & 32.5187 & Northwest \\
\hline 13 & Cool temperate steppe & 123.6467 & Northwest & 220.6709 & Southwest & 66.4193 & Northwest \\
\hline 14 & Cool temperate moist forest & 227.0825 & Northwest & 168.4700 & Southwest & 11.1340 & Northwest \\
\hline 15 & Cool temperate wet forest & 123.9504 & Northeast & 95.6483 & Northeast & 130.3338 & Northeast \\
\hline 16 & Cool temperate rain forest & 95.4109 & Southwest & 28.6009 & Southeast & 15.2249 & Southeast \\
\hline 17 & Warm temperate desert & 38.6474 & East & 79.3850 & West & 32.5365 & Northeast \\
\hline 18 & Warm temperate desert scrub & 217.7506 & Northeast & 72.2842 & North & 125.3002 & Northeast \\
\hline 19 & Warm temperate thorn steppe & 253.4637 & Northeast & 232.9484 & Southeast & 13.5248 & Northeast \\
\hline 20 & Warm temperate dry forest & 81.5412 & Northeast & 13.1024 & Southwest & 139.4464 & North \\
\hline 21 & Warm temperate moist forest & 130.0008 & Southeast & 322.9908 & Northwest & 45.9446 & Northwest \\
\hline 22 & Warm temperate wet forest & 205.8891 & West & 129.8224 & Southeast & 55.3369 & Southwest \\
\hline 24 & Subtropical desert & & & & & 36.4379 & Northwest \\
\hline 25 & Subtropical desert scrub & & & 45.6468 & Northwest & 18.2872 & Northwest \\
\hline 26 & Subtropical thorn woodland & 5.0000 & West & 869.6082 & Northwest & 448.5919 & Northwest \\
\hline 27 & Subtropical dry forest & 58.7632 & Southeast & 371.4169 & Northwest & 108.5210 & Northwest \\
\hline 28 & Subtropical moist forest & 245.9084 & Northwest & 31.2406 & Southeast & 303.1905 & Southwest \\
\hline 29 & Subtropical wet forest & 629.2746 & Southwest & 1809.9737 & Northeast & 115.1788 & Northwest \\
\hline 31 & Tropical desert & 59.8149 & Northeast & 59.1494 & Southwest & 11.8325 & Northeast \\
\hline 34 & Tropical very dry forest & 110.0239 & Northwest & 151.6962 & Southwest & 190.1670 & Northwest \\
\hline 35 & Tropical dry forest & 43.0813 & East & 341.9647 & Southwest & 83.2305 & Northeast \\
\hline 36 & Tropical moist forest & 174.5450 & Northwest & 357.3161 & Southeast & 35.2427 & Northwest \\
\hline 37 & Tropical wet forest & & & & & & \\
\hline
\end{tabular}


Mountains, the northwest of Tianshan Mountains, Qarqan River area of the northern Altun Mountains and Yarkant River area of the western Tarim basin. The boreal moist, wet and rain forests, and cool temperate moist and wet forests would be distributed in the east and the south of Qinghai-Xizang Plateau and Da Hinggan, Xiao Hinggan and Taihang mountains. The warm temperate dry forest would appear in most of the North China Plain, while the warm temperate moist and wet forests would be found in the north of the YunnanGuizhou Plateau and most of the lower reaches of the Yangtze River. Subtropical dry, moist and wet forests would be distributed mainly in the south of the Yunnan-Guizhou Plateau, the Nanling Mountains, the Jiangnan Hills and its southern area, and the high mountains of Taiwan. Tropical dry forest would occur in the western Hainan; tropical moist forest in the eastern Hainan, Hong Kong and the low mountains of Taiwan; and tropical wet forests in the archipelagoes of the South China Sea.

\subsection{HLZ mean-center shift}

According to HadCM2 (Table 2; Fig. 4), HLZ types that would have their cumulative shift distances of mean centers shortened by less than $200 \mathrm{~km}$ from T1 to T4 include nival areas $(37 \mathrm{~km})$, subtropical desert scrub $(64 \mathrm{~km})$, alpine wet tundra $(91 \mathrm{~km})$, tropical desert $(131 \mathrm{~km})$, boreal desert $(135 \mathrm{~km})$, cool temperate rain forest $(139 \mathrm{~km})$, boreal dry scrub $(148 \mathrm{~km})$, warm temperate desert $(151 \mathrm{~km})$ and cool temperate scrub $(161 \mathrm{~km})$. The HLZ types that would see the range of their cumulative shift distances move between $200 \mathrm{~km}$ and $1000 \mathrm{~km}$ over the four periods include boreal rain forest $(204 \mathrm{~km})$, alpine rain tundra $(206 \mathrm{~km})$, alpine dry tundra $(227 \mathrm{~km})$, warm temperate dry forest $(239 \mathrm{~km})$, cool temperate desert $(270 \mathrm{~km})$, cool temperate wet forest $(350 \mathrm{~km})$, alpine moist tundra $(379 \mathrm{~km})$, warm temperate wet forest $(391 \mathrm{~km})$, cool temperate moist forest $(406 \mathrm{~km})$, cool temperate steppe $(411 \mathrm{~km})$, warm temperate desert scrub $(415 \mathrm{~km})$, tropical very dry forest (452 km), tropical

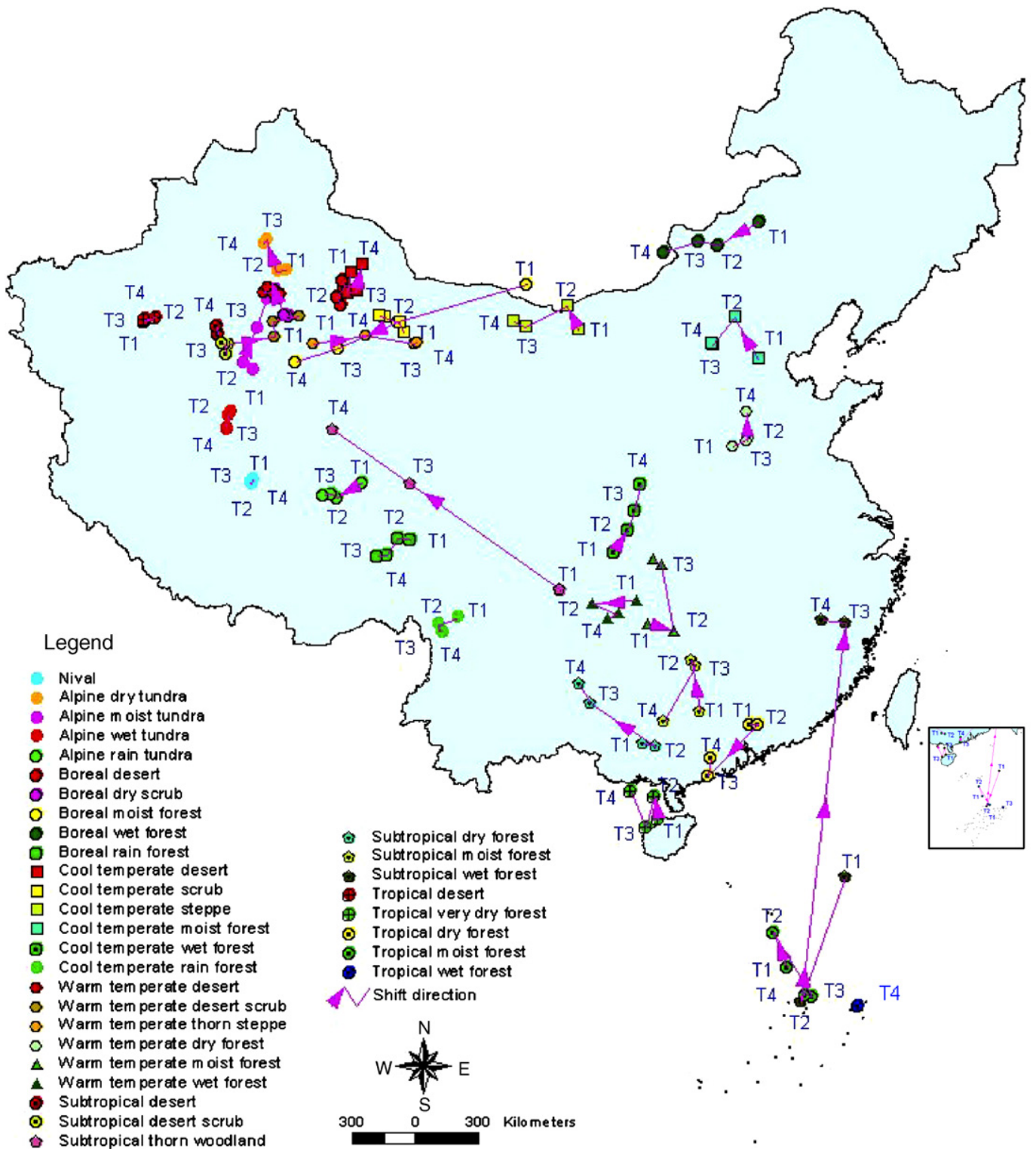

Fig. 4 - Holdridge Life Zone mean-center shift predicted by HadCM2 for the periods 1961-1990 (T1), 2010-2039 (T2), 2040-2069 (T3) and 2070-2099 (T4). 
dry forest $(468 \mathrm{~km})$, boreal wet forest $(491 \mathrm{~km})$, warm temperate moist forest $(499 \mathrm{~km})$, warm temperate thorn steppe $(500 \mathrm{~km})$, subtropical dry forest $(539 \mathrm{~km})$, tropical moist forest $(567 \mathrm{~km})$ and subtropical moist forest $(580 \mathrm{~km})$. Boreal moist forest, subtropical thorn woodland and subtropical wet forest would see their cumulative shift distances move by more than $1000 \mathrm{~km}$. The mean center of boreal moist forest would continuously shift, moving $1159 \mathrm{~km}$ towards the southwest during the four periods; subtropical thorn woodland would shift $5 \mathrm{~km}$ towards the west from T1 to T2 and then continuously, moving $1318 \mathrm{~km}$ towards the northwest from T2 to T3 and from T3 to T4. Subtropical wet forest would shift $629 \mathrm{~km}$ towards the southwest from T1 to T2, $1810 \mathrm{~km}$ towards the northeast from T2 to T3 and $115 \mathrm{~km}$ towards the northwest from T3 to T4.

According to HadCM3 (Table 3; Fig. 5), the HLZ types that would see their cumulative shift distances shortened by less than $200 \mathrm{~km}$ from T1 to T4 include tropical desert $(19 \mathrm{~km})$, tropical wet forest $(43 \mathrm{~km})$, boreal desert $(158 \mathrm{~km})$ and alpine dry tundra $(189 \mathrm{~km})$. The HLZ types with cumulative shift distances between $200 \mathrm{~km}$ and $1000 \mathrm{~km}$ include warm temperate desert $(223 \mathrm{~km})$, cool temperate desert $(244 \mathrm{~km})$, warm temperate desert scrub $(263 \mathrm{~km})$, alpine wet tundra $(297 \mathrm{~km})$, alpine moist tundra $(309 \mathrm{~km})$, nival areas $(321 \mathrm{~km})$, tropical moist forest $(337 \mathrm{~km})$, cool temperate scrub $(404 \mathrm{~km})$, alpine rain tundra $(425 \mathrm{~km})$, boreal dry scrub $(428 \mathrm{~km})$, boreal moist forest $(433 \mathrm{~km})$, cool temperate steppe $(521 \mathrm{~km})$, boreal rain forest $(547 \mathrm{~km})$, warm temperate thorn steppe $(635 \mathrm{~km})$, subtropical wet forest $(651 \mathrm{~km})$, warm temperate dry forest (669 km), warm temperate moist forest $(675 \mathrm{~km})$, cool temperate wet forest $(728 \mathrm{~km})$, cool temperate rain forest $(794 \mathrm{~km})$ and tropical dry forest $(863 \mathrm{~km})$. Cumulative shift distances greater than $1000 \mathrm{~km}$ include subtropical moist forest $(1104 \mathrm{~km})$, cool temperate moist forest $(1336 \mathrm{~km})$, warm temperate wet forest $(1435 \mathrm{~km})$, boreal wet forest $(2196 \mathrm{~km})$ and subtropical dry forest $(2272 \mathrm{~km})$. The mean center of subtropical moist forest would shift $156 \mathrm{~km}$ towards the southwest from T1 to T2, $436 \mathrm{~km}$ towards the north from T2 to T3 and $513 \mathrm{~km}$ towards the southwest from T3 to T4. The cool temperate moist forest would shift $401 \mathrm{~km}$ towards the northwest from T1 to T2, $329 \mathrm{~km}$ towards the southwest from T2 to T3 and $606 \mathrm{~km}$ towards the northeast from $\mathrm{T} 3$ to $\mathrm{T} 4$. The warm temperate wet forest would shift $179 \mathrm{~km}$ towards the northwest from T1 to T2, $846 \mathrm{~km}$ towards the west from T2 to T3 and $411 \mathrm{~km}$ towards the northwest from T3 to T4. The boreal wet forest would shift continuously, moving $2196 \mathrm{~km}$ towards the southwest during the four periods. The subtropical dry forest would disappear during T2 and T3 and reappear in T4, and its mean center would shift $2272 \mathrm{~km}$ towards the northeast from T1 to T4.

Table 3 - Holdridge Life Zone mean-center shift predicted by HadCM3

\begin{tabular}{|c|c|c|c|c|c|c|c|}
\hline \multirow[t]{2}{*}{ Code } & \multirow[t]{2}{*}{ HLZ type (name) } & \multicolumn{2}{|c|}{ From T1 to T2 } & \multicolumn{2}{|c|}{ From T2 to T3 } & \multicolumn{2}{|c|}{ From T3 to T4 } \\
\hline & & Distance (km) & Direction & Distance $(\mathrm{km})$ & Direction & Distance $(\mathrm{km})$ & Direction \\
\hline 1 & Nival & 124.4070 & Northwest & 74.8280 & Southwest & 122.0751 & Northwest \\
\hline 2 & Alpine dry tundra & 94.2771 & Northeast & 11.1873 & Northeast & 83.6462 & West \\
\hline 3 & Alpine moist tundra & 126.6003 & Northwest & 115.8568 & Northwest & 66.5508 & Northwest \\
\hline 4 & Alpine wet tundra & 68.3549 & Northeast & 120.5977 & Northeast & 108.2577 & Southwest \\
\hline 5 & Alpine rain tundra & 118.8643 & Northwest & 191.8150 & Northwest & 114.0076 & West \\
\hline 6 & Boreal desert & 70.4827 & Northwest & 56.1247 & Northwest & 31.0157 & Northeast \\
\hline 7 & Boreal dry scrub & 77.5663 & Northwest & 195.7217 & Northwest & 154.2397 & Northwest \\
\hline 8 & Boreal moist forest & 286.8680 & Southwest & 123.1138 & Northwest & 23.0960 & Northwest \\
\hline 9 & Boreal wet forest & 558.5189 & Southwest & 1006.3419 & Southwest & 631.1571 & Southwest \\
\hline 10 & Boreal rain forest & 46.9533 & Northwest & 196.5050 & Southwest & 303.8355 & Northwest \\
\hline 11 & Cool temperate desert & 90.5719 & Northeast & 97.0943 & East & 56.0373 & Northwest \\
\hline 12 & Cool temperate scrub & 95.7755 & Northwest & 139.9974 & Northwest & 168.4242 & West \\
\hline 13 & Cool temperate steppe & 62.6888 & Southwest & 123.1965 & Northwest & 335.4326 & Northwest \\
\hline 14 & Cool temperate moist forest & 401.2267 & Northwest & 328.5963 & Southwest & 605.9601 & Northeast \\
\hline 15 & Cool temperate wet forest & 116.6780 & Northeast & 357.6011 & Northeast & 254.0943 & Northwest \\
\hline 16 & Cool temperate rain forest & 661.1538 & Southwest & 76.6340 & Southeast & 56.2465 & Northwest \\
\hline 17 & Warm temperate desert & 116.7835 & Northeast & 58.0957 & Southwest & 47.9030 & Northeast \\
\hline 18 & Warm temperate desert scrub & 60.8555 & Northeast & 146.5193 & East & 55.7731 & Northeast \\
\hline 19 & Warm temperate thorn steppe & 325.5924 & Northeast & 223.2580 & East & 85.9428 & Northwest \\
\hline 20 & Warm temperate dry forest & 171.3690 & Northwest & 237.9701 & Northwest & 259.4049 & Northwest \\
\hline 21 & Warm temperate moist forest & 248.2847 & Northeast & 159.7227 & Northwest & 266.5399 & Northwest \\
\hline 22 & Warm temperate wet forest & 178.4653 & Northwest & 845.5714 & West & 410.5398 & West \\
\hline 24 & Subtropical desert & & & & & 149.9273 & Northwest \\
\hline 25 & Subtropical desert scrub & & & & & 52.1445 & Northwest \\
\hline 26 & Subtropical thorn woodland & & & & & 43.0437 & Southwest \\
\hline 27 & Subtropical dry forest & & & & & & \\
\hline 28 & Subtropical moist forest & 155.8283 & Southwest & 435.8816 & North & 512.4857 & Southwest \\
\hline 29 & Subtropical wet forest & 110.3578 & Northwest & 153.5290 & Southwest & 387.1327 & Northwest \\
\hline 31 & Tropical desert & 5.0000 & East & 8.5715 & West & 5.2001 & Northwest \\
\hline 35 & Tropical dry forest & & & 847.8571 & Southeast & 14.7862 & Northwest \\
\hline 36 & Tropical moist forest & 77.6888 & West & 105.0244 & Northwest & 153.9917 & Northwest \\
\hline 37 & Tropical wet forest & 34.6386 & Northwest & 59.2569 & North & 36.8389 & Southeast \\
\hline
\end{tabular}




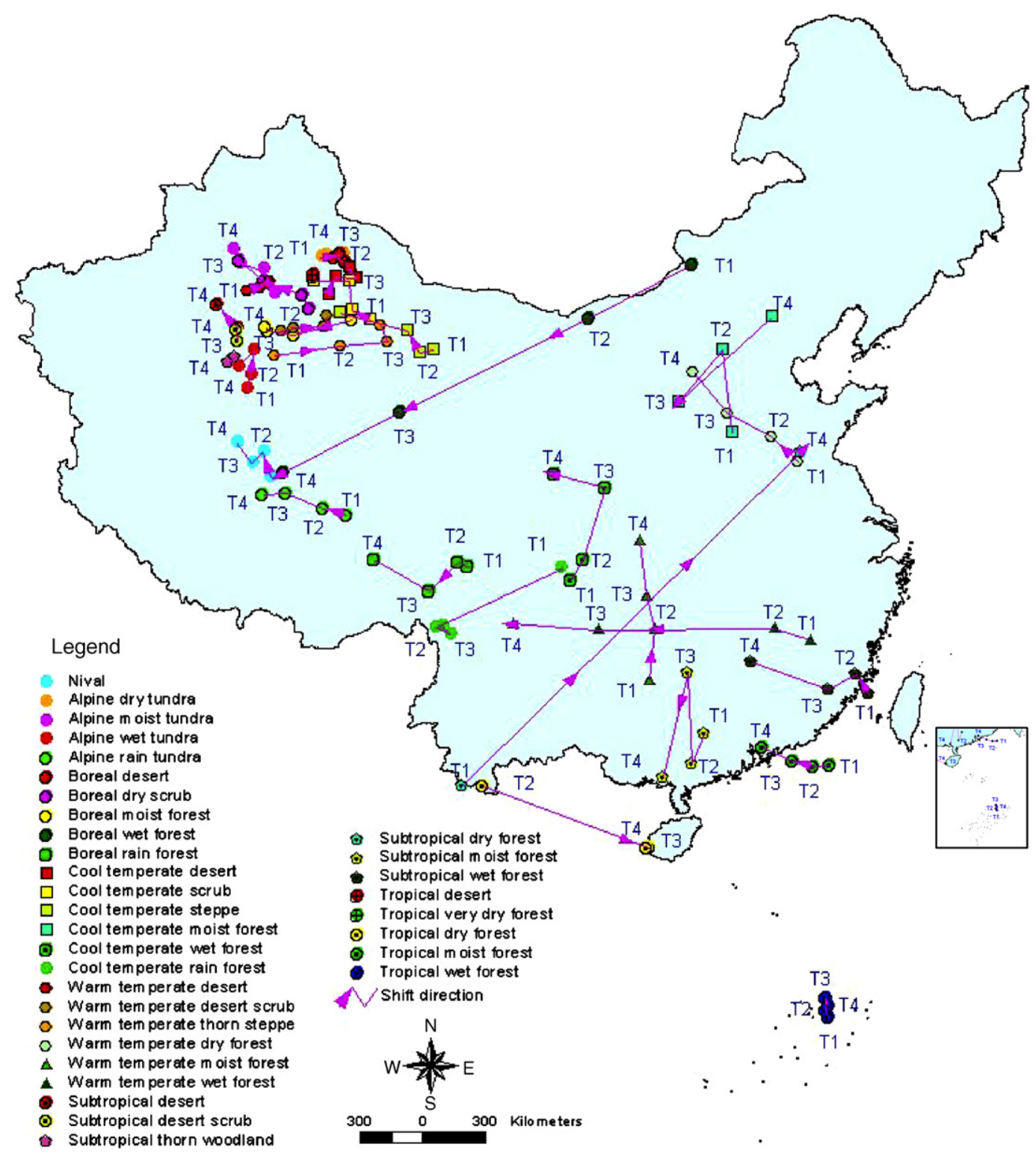

Fig. 5 - Holdridge Life Zone mean-center shift predicted by HadCM3 for the periods 1961-1990 (T1), $2010-2039$ (T2), 2040-2069 (T3) and 2070-2099 (T4).

\subsection{Average HLZ area changes}

Based on the HadCM2 simulation, HLZ types that would have an areal extent larger than 10 million ha on average included nival areas, cool temperate moist forest, warm temperate moist forest, subtropical moist forest, boreal wet forest, cool temperate steppe, warm temperate desert, alpine rain tundra, cool temperate wet forest, boreal rain forest, cool temperate scrub, subtropical dry forest, warm temperate dry forest, cool temperate desert, boreal moist forest, warm temperate desert scrub, tropical dry forest and alpine wet tundra (Table 4). Tropical wet forest, tropical moist forest, subtropical desert, subtropical wet forest, subtropical thorn woodland, alpine dry tundra, tropical very dry forest, subtropical desert scrub, alpine moist tundra, boreal desert, boreal dry scrub, cool temperate rain forest, tropical desert, warm temperate wet forest and warm temperate thorn steppe underwent an area change of less than 10 million ha. The HLZ types whose area decreased continuously during the four periods (Table 5) include nival zone, alpine moist tundra, boreal desert, boreal dry scrub, boreal moist forest, cool temperate desert, cool temperate scrub, cool temperate wet forest and warm temperate moist forest. Alpine wet tundra, alpine rain tundra, boreal rain forest, cool temperate rain forest, warm temperate desert scrub, warm temperate thorn steppe, subtropical desert, subtropical moist forest and tropical dry forest showed a continuous increase in areal extent during the four periods.

Based on the HadCM3 simulation, HLZ types that would have an area larger than 10 million ha on average include cool temperate moist forest, subtropical moist forest, warm temperate moist forest, nival areas, boreal wet forest, alpine rain tundra, warm temperate dry forest, cool temperate steppe, cool temperate wet forest, boreal rain forest, warm temperate desert scrub, cool temperate scrub, cool temperate desert, 
Table 4 - Area (million ha) of each Holdridge Life Zone type predicted by HadCM2

\begin{tabular}{|c|c|c|c|c|c|c|}
\hline Code & HLZ type & $\mathrm{T} 1$ & $\mathrm{~T} 2$ & T3 & $\mathrm{T} 4$ & Average \\
\hline 1 & Nival & 150.2506 & 134.9758 & 122.4263 & 112.2238 & 129.9691 \\
\hline 2 & Alpine dry tundra & 1.9102 & 1.9919 & 0.8971 & 0.7571 & 1.3891 \\
\hline 3 & Alpine moist tundra & 3.5219 & 3.3135 & 2.9595 & 2.1609 & 2.989 \\
\hline 4 & Alpine wet tundra & 9.234 & 9.7529 & 10.5353 & 10.9642 & 10.1216 \\
\hline 5 & Alpine rain tundra & 44.0494 & 44.927 & 47.7646 & 48.9187 & 46.4149 \\
\hline 6 & Boreal desert & 8.2232 & 6.4733 & 3.9724 & 3.1 & 5.4422 \\
\hline 7 & Boreal dry scrub & 7.0476 & 6.4505 & 6.1645 & 5.7634 & 6.3565 \\
\hline 8 & Boreal moist forest & 21.1151 & 14.0923 & 13.8538 & 12.7914 & 15.4631 \\
\hline 9 & Boreal wet forest & 64.0624 & 52.8971 & 53.0569 & 48.4823 & 54.6247 \\
\hline 10 & Boreal rain forest & 37.5379 & 38.6973 & 39.5161 & 42.2789 & 39.5076 \\
\hline 11 & Cool temperate desert & 34.6583 & 30.1473 & 27.749 & 25.2188 & 29.4434 \\
\hline 12 & Cool temperate scrub & 34.3058 & 32.376 & 32.3421 & 28.4917 & 31.8789 \\
\hline 13 & Cool temperate steppe & 52.6884 & 51.2058 & 50.8419 & 46.9681 & 50.426 \\
\hline 14 & Cool temperate moist forest & 104.5457 & 121.1219 & 127.0342 & 129.8499 & 120.6379 \\
\hline 15 & Cool temperate wet forest & 46.6909 & 45.8087 & 39.9543 & 38.7208 & 42.7937 \\
\hline 16 & Cool temperate rain forest & 5.0712 & 5.6851 & 6.9383 & 7.7876 & 6.3706 \\
\hline 17 & Warm temperate desert & 51.723 & 55.465 & 46.2715 & 45.7553 & 49.8037 \\
\hline 18 & Warm temperate desert scrub & 8.7875 & 11.8125 & 14.7555 & 17.4259 & 13.1953 \\
\hline 19 & Warm temperate thorn steppe & 2.69 & 6.2136 & 12.94 & 16.8036 & 9.6618 \\
\hline 20 & Warm temperate dry forest & 20.5765 & 24.6689 & 33.5267 & 40.2289 & 29.7503 \\
\hline 21 & Warm temperate moist forest & 118.2711 & 101.6729 & 89.2205 & 74.8149 & 95.9949 \\
\hline 22 & Warm temperate wet forest & 6.4688 & 6.1378 & 9.887 & 11.2504 & 8.436 \\
\hline 24 & Subtropical desert & & & 0.12 & 1.77 & 0.4725 \\
\hline 25 & Subtropical desert scrub & & 0.43 & 2.65 & 3.99 & 1.7675 \\
\hline 26 & Subtropical thorn woodland & 0.68 & 0.66 & 1.01 & 1.44 & 0.9475 \\
\hline 27 & Subtropical dry forest & 41.0577 & 44.1673 & 20.8644 & 16.5104 & 30.65 \\
\hline 28 & Subtropical moist forest & 63.5571 & 83.0373 & 105.3638 & 123.5338 & 93.873 \\
\hline 29 & Subtropical wet forest & 0.0556 & 0.0451 & 0.9712 & 1.6411 & 0.6783 \\
\hline 31 & Tropical desert & 6.71 & 7.38 & 6.1 & 5.4 & 6.3975 \\
\hline 34 & Tropical very dry forest & 1.1643 & 3.1287 & 1.1882 & 1.1569 & 1.6596 \\
\hline 35 & Tropical dry forest & 2.7073 & 4.6316 & 18.4487 & 23.1234 & 12.2277 \\
\hline 36 & Tropical moist forest & 0.0217 & 0.0151 & 0.0583 & 0.0516 & 0.0367 \\
\hline 37 & Tropical wet forest & & & & 0.0075 & 0.0019 \\
\hline
\end{tabular}

warm temperate desert, warm temperate thorn steppe, boreal moist forest and warm temperate wet forest (Table 6). Tropical wet forest, tropical desert, tropical dry forest, alpine dry tundra, boreal desert, subtropical thorn woodland, alpine moist tundra, cool temperate rain forest, subtropical dry forest, subtropical desert, subtropical desert scrub, boreal dry scrub, alpine wet tundra, subtropical wet forest and tropical moist forest would decrease in area by less than 10 million ha. The HLZ types whose area would decrease continuously during the four periods include nival areas, alpine dry tundra, alpine moist tundra, alpine wet tundra, boreal desert, boreal dry scrub, boreal moist forest, boreal wet forest, cool temperate desert, cool temperate scrub and warm temperate moist forest (Table 7). Warm temperate desert scrub, warm temperate thorn steppe, warm temperate dry forest, subtropical moist forest, subtropical wet forest and tropical moist forest would undergo a continuous increase in areal extent during the four periods.

\section{Discussion}

Based on both HadCM2 and HadCM3, the nival areas in the Qinghai-Xizang Plateau would rapidly shrink towards the northwest and the nival zones in the Tianshan and Qilian mountains would shrink back to the mountaintops in response to the projected increase in temperature and precipitation (Tables 5 and 7; Figs. 2 and 3). HadCM3 predicted a faster rate of shrinking than did HadCM2. Except for desert and desert scrub, warm temperate HLZ and subtropical HLZ types currently are distributed south of the Yangtze River, while they would cross the Yangtze River and shift towards the north in the 21st century. Tropical dry and tropical moist forests would expand from the southeastern coastal area towards the north, with HadCM3 predicting a faster expansion rate than HadCM2. Arid HLZ types, such as warm temperate desert scrub and warm temperate thorn steppe, would increase continuously, which means that desertification might become a more serious problem in the 21st century in China. The area of arid and cold HLZ types would gradually decrease and be replaced by HLZ types characteristic of arid and warm environments, such as warm temperate desert scrub, warm temperate thorn steppe and warm temperate dry forest.

Nival areas, cool temperate moist forest, warm temperate moist forest, subtropical moist forest and boreal wet forest would be the five HLZ types with the biggest area according to both HadCM2 and HadCM3. The combined area of these five HLZ types would be greater than $50 \%$ of China's land mass. Among these five HLZ types, nival areas and warm temperate moist and boreal wet forests would decrease continuously by 38 million ha, 43 million ha and 16 million ha, respectively, during the four periods, while subtropical moist and cool tem- 
Table 5 - Area (million ha) change of each Holdridge Life Zone type predicted by HadCM2

\begin{tabular}{|c|c|c|c|c|c|c|c|}
\hline \multirow[t]{2}{*}{ Code } & \multirow[t]{2}{*}{ HLZ type (name) } & \multicolumn{2}{|c|}{ From $\mathrm{T} 1$ to $\mathrm{T} 2$} & \multicolumn{2}{|c|}{ From T2 to T3 } & \multicolumn{2}{|c|}{ From $\mathrm{T} 3$ to $\mathrm{T} 4$} \\
\hline & & $\begin{array}{c}\text { Increase in } \\
\text { area }\end{array}$ & $\begin{array}{c}\text { Rate of } \\
\text { increase (\%) }\end{array}$ & $\begin{array}{c}\text { Increase in } \\
\text { area }\end{array}$ & $\begin{array}{c}\text { Rate of } \\
\text { increase (\%) }\end{array}$ & $\begin{array}{c}\text { Increase in } \\
\text { area }\end{array}$ & $\begin{array}{c}\text { Rate of } \\
\text { increase (\%) }\end{array}$ \\
\hline 1 & Nival & -15.2748 & -10.1662 & -12.5495 & -9.2976 & -10.2024 & -8.3335 \\
\hline 2 & Alpine dry tundra & 0.0817 & 4.2751 & -1.0948 & -54.9617 & -0.1400 & -15.6054 \\
\hline 3 & Alpine moist tundra & -0.2084 & -5.9160 & -0.3540 & -10.6837 & -0.7986 & -26.9838 \\
\hline 4 & Alpine wet tundra & 0.5189 & 5.6195 & 0.7824 & 8.0223 & 0.4289 & 4.0711 \\
\hline 5 & Alpine rain tundra & 0.8776 & 1.9923 & 2.8376 & 6.3161 & 1.1541 & 2.4161 \\
\hline 6 & Boreal desert & -1.7499 & -21.2800 & -2.5009 & -38.6341 & -0.8724 & -21.9611 \\
\hline 7 & Boreal dry scrub & -0.5971 & -8.4723 & -0.2860 & -4.4340 & -0.4011 & -6.5069 \\
\hline 8 & Boreal moist forest & -7.0228 & -33.2594 & -0.2385 & -1.6923 & -1.0624 & -7.6690 \\
\hline 9 & Boreal wet forest & -11.1653 & -17.4288 & 0.1598 & 0.3021 & -4.5746 & -8.6221 \\
\hline 10 & Boreal rain forest & 1.1594 & 3.0887 & 0.8188 & 2.1158 & 2.7629 & 6.9917 \\
\hline 11 & Cool temperate desert & -4.5110 & -13.0156 & -2.3983 & -7.9553 & -2.5303 & -9.1184 \\
\hline 12 & Cool temperate scrub & -1.9298 & -5.6253 & -0.0339 & -0.1047 & -3.8504 & -11.9053 \\
\hline 13 & Cool temperate steppe & -1.4826 & -2.8139 & -0.3640 & -0.7108 & -3.8737 & -7.6192 \\
\hline 14 & Cool temperate moist forest & 16.5762 & 15.8555 & 5.9123 & 4.8813 & 2.8157 & 2.2165 \\
\hline 15 & Cool temperate wet forest & -0.8822 & -1.8894 & -5.8545 & -12.7802 & -1.2334 & -3.0871 \\
\hline 16 & Cool temperate rain forest & 0.6139 & 12.1046 & 1.2532 & 22.0443 & 0.8493 & 12.2405 \\
\hline 17 & Warm temperate desert & 3.7420 & 7.2346 & -9.1935 & -16.5754 & -0.5162 & -1.1155 \\
\hline 18 & Warm temperate desert scrub & 3.0250 & 34.4243 & 2.9430 & 24.9146 & 2.6704 & 18.0978 \\
\hline 19 & Warm temperate thorn steppe & 3.5236 & 130.9873 & 6.7264 & 108.2541 & 3.8636 & 29.8579 \\
\hline 20 & Warm temperate dry forest & 4.0924 & 19.8886 & 8.8578 & 35.9067 & 6.7022 & 19.9907 \\
\hline 21 & Warm temperate moist forest & -16.5982 & -14.0341 & -12.4523 & -12.2475 & -14.4056 & -16.1460 \\
\hline 22 & Warm temperate wet forest & -0.3310 & -5.1168 & 3.7493 & 61.0852 & 1.3634 & 13.7895 \\
\hline 24 & Subtropical desert & & & 0.1200 & & 1.6500 & 1374.9999 \\
\hline 25 & Subtropical desert scrub & 0.4300 & & 2.2200 & 516.2791 & 1.3400 & 50.5660 \\
\hline 26 & Subtropical thorn woodland & -0.0200 & -2.9412 & 0.3500 & 53.0303 & 0.4300 & 42.5743 \\
\hline 27 & Subtropical dry forest & 3.1096 & 7.5737 & -23.3029 & -52.7606 & -4.3540 & -20.8682 \\
\hline 28 & Subtropical moist forest & 19.4801 & 30.6498 & 22.3265 & 26.8873 & 18.1700 & 17.2451 \\
\hline 29 & Subtropical wet forest & -0.0105 & -18.9094 & 0.9261 & 2053.3004 & 0.6699 & 68.9715 \\
\hline 31 & Tropical desert & 0.6700 & 9.9851 & -1.2800 & -17.3442 & -0.7000 & -11.4754 \\
\hline 34 & Tropical very dry forest & 1.9644 & 168.7180 & -1.9405 & -62.0214 & -0.0313 & -2.6353 \\
\hline 35 & Tropical dry forest & 1.9242 & 71.0757 & 13.8171 & 298.3252 & 4.6747 & 25.3387 \\
\hline 36 & Tropical moist forest & -0.0066 & -30.3427 & 0.0432 & 285.8839 & -0.0067 & -11.5440 \\
\hline 37 & Tropical wet forest & & & & & 0.0075 & \\
\hline
\end{tabular}

perate forests would increase continuously by 60 million ha and 25 million ha, respectively (Figs. 6 and 7; Tables 4 and 6). These changes would alter terrestrial ecosystem services in China considerably.

In terms of the mean-center model, the shift ranges of HLZ types would be markedly greater based on the simula- tion using HadCM3 data compared with HadCM2, in general. The results from both HadCM2 and HadCM3 showed that boreal wet forest, subtropical moist forest, tropical dry forest, warm temperate moist forest and subtropical wet forest would have a bigger shift range, indicating that these HLZ types are more sensitive to the climate change scenarios simulated by

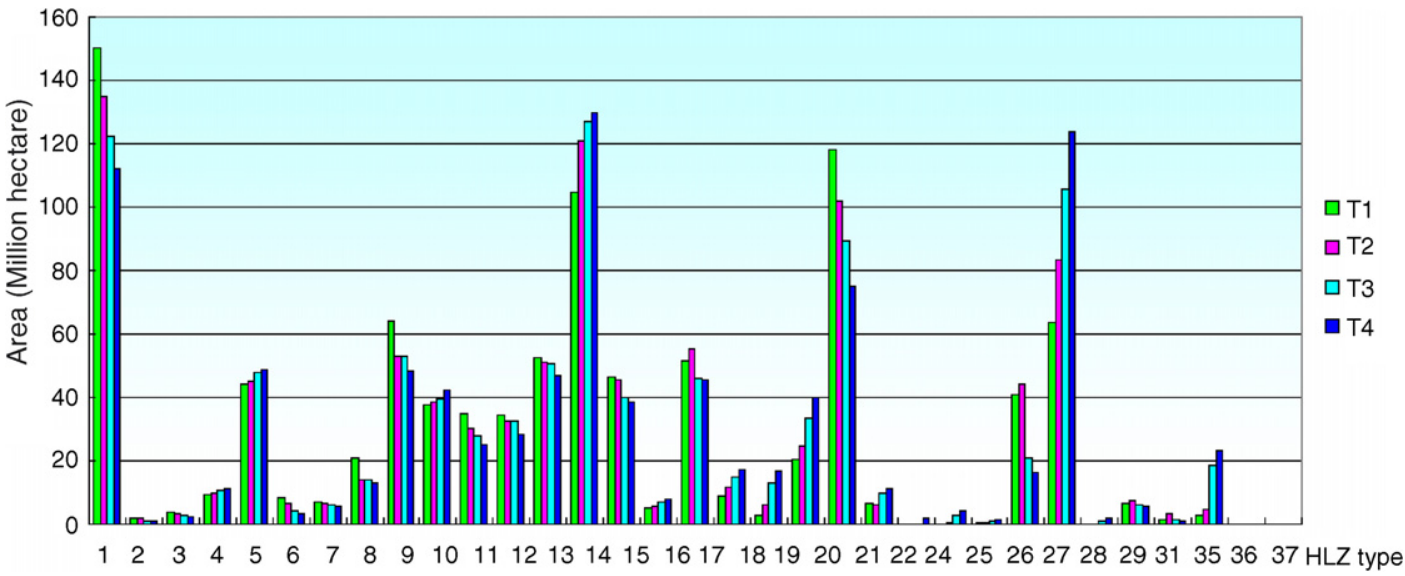

Fig. 6 - Area change of each Holdridge Life Zone type predicted by HadCM2 for the periods 1961-1990 (T1), 2010-2039 (T2), 2040-2069 (T3) and 2070-2099 (T4). 
Table 6 - Area (million ha) of each Holdridge Life Zone type predicted by HadCM3

\begin{tabular}{|c|c|c|c|c|c|c|}
\hline Code & HLZ type & $\mathrm{T} 1$ & $\mathrm{~T} 2$ & T3 & $\mathrm{T} 4$ & Average \\
\hline 1 & Nival & 133.3525 & 109.2512 & 68.5638 & 30.7545 & 85.4805 \\
\hline 2 & Alpine dry tundra & 0.41 & 0.3619 & 0.3026 & 0.17 & 0.3111 \\
\hline 3 & Alpine moist tundra & 2.806 & 2.0166 & 1.5161 & 1.04 & 1.8447 \\
\hline 4 & Alpine wet tundra & 9.1413 & 7.0844 & 5.1115 & 4.4639 & 6.4503 \\
\hline 5 & Alpine rain tundra & 60.4742 & 66.7798 & 67.9223 & 54.2776 & 62.3635 \\
\hline 6 & Boreal desert & 3.0052 & 1.4068 & 0.84 & 0.6271 & 1.4698 \\
\hline 7 & Boreal dry scrub & 8.9302 & 5.6615 & 3.7826 & 2.8178 & 5.298 \\
\hline 8 & Boreal moist forest & 15.549 & 13.761 & 11.3866 & 9.1018 & 12.4496 \\
\hline 9 & Boreal wet forest & 86.3131 & 65.0367 & 55.8743 & 53.759 & 65.2458 \\
\hline 10 & Boreal rain forest & 25.9707 & 30.2383 & 37.0423 & 48.8282 & 35.5199 \\
\hline 11 & Cool temperate desert & 44.7555 & 33.0334 & 17.9614 & 5.2283 & 25.2446 \\
\hline 12 & Cool temperate scrub & 39.2906 & 36.1426 & 21.8211 & 9.7506 & 26.7512 \\
\hline 13 & Cool temperate steppe & 45.5211 & 49.6304 & 41.2574 & 29.2733 & 41.4206 \\
\hline 14 & Cool temperate moist forest & 140.4889 & 165.2606 & 176.1198 & 161.4196 & 160.8222 \\
\hline 15 & Cool temperate wet forest & 42.2757 & 37.5041 & 40.6728 & 42.8885 & 40.8353 \\
\hline 16 & Cool temperate rain forest & 0.377 & 0.8416 & 2.2847 & 4.4949 & 1.9996 \\
\hline 17 & Warm temperate desert & 22.3657 & 16.5007 & 32.9674 & 26.3792 & 24.5532 \\
\hline 18 & Warm temperate desert scrub & 13.8142 & 24.6593 & 37.5161 & 46.405 & 30.5986 \\
\hline 19 & Warm temperate thorn steppe & 7.32 & 18.0248 & 26.5009 & 41.4475 & 23.3233 \\
\hline 20 & Warm temperate dry forest & 33.0814 & 39.9026 & 39.9059 & 54.7349 & 41.9062 \\
\hline 21 & Warm temperate moist forest & 139.2936 & 122.7745 & 84.6871 & 51.4013 & 99.5391 \\
\hline 22 & Warm temperate wet forest & 7.6439 & 9.1917 & 8.9468 & 14.2244 & 10.0017 \\
\hline 24 & Subtropical desert & & & 0.1 & 10.8677 & 2.7419 \\
\hline 25 & Subtropical desert scrub & & & 1.93 & 9.2279 & 2.7895 \\
\hline 26 & Subtropical thorn woodland & & & 2.88 & 4.02 & 1.725 \\
\hline 27 & Subtropical dry forest & 0.0005 & & & 8.3364 & 2.0842 \\
\hline 28 & Subtropical moist forest & 61.5946 & 85.4271 & 139.3057 & 186.4402 & 118.1919 \\
\hline 29 & Subtropical wet forest & 3.0251 & 4.531 & 12.4354 & 13.5458 & 8.3843 \\
\hline 31 & Tropical desert & 0.02 & 0.01 & 0.07 & 0.15 & 0.0625 \\
\hline 35 & Tropical dry forest & & 0.046 & 0.0352 & 0.2696 & 0.0877 \\
\hline 36 & Tropical moist forest & 2.5151 & 4.2539 & 9.5889 & 22.9878 & 9.8364 \\
\hline 37 & Tropical wet forest & 0.0482 & 0.0511 & 0.0538 & 0.0503 & 0.0508 \\
\hline
\end{tabular}

HadCM2 and HadCM3 (Tables 2 and 3; Figs. 4 and 5). The continuous shift of both boreal dry and cool temperate scrubs towards the northwest in the 21st century means that the HLZ types present in arid environments would move towards the northwest in response to the projected temperature and precipitation increase in northwest China. Mean centers of alpine moist tundra and cool temperature wet forest would shift towards the north in general, possibly because of the areal expansion of the two HLZ types in the high mountains of northern China and the precipitation increase in northern China. HLZ types in cold and frigid environments, such as alpine moist tundra, would be replaced by other HLZ types, such as boreal wet forest, such that the relative ratio of boreal forest in Qinghai-Xizang Plateau to that in the Da Hinggan, Xiao Hinggan and Changbai mountains would increase in the 21st century because of temperature and precipitation

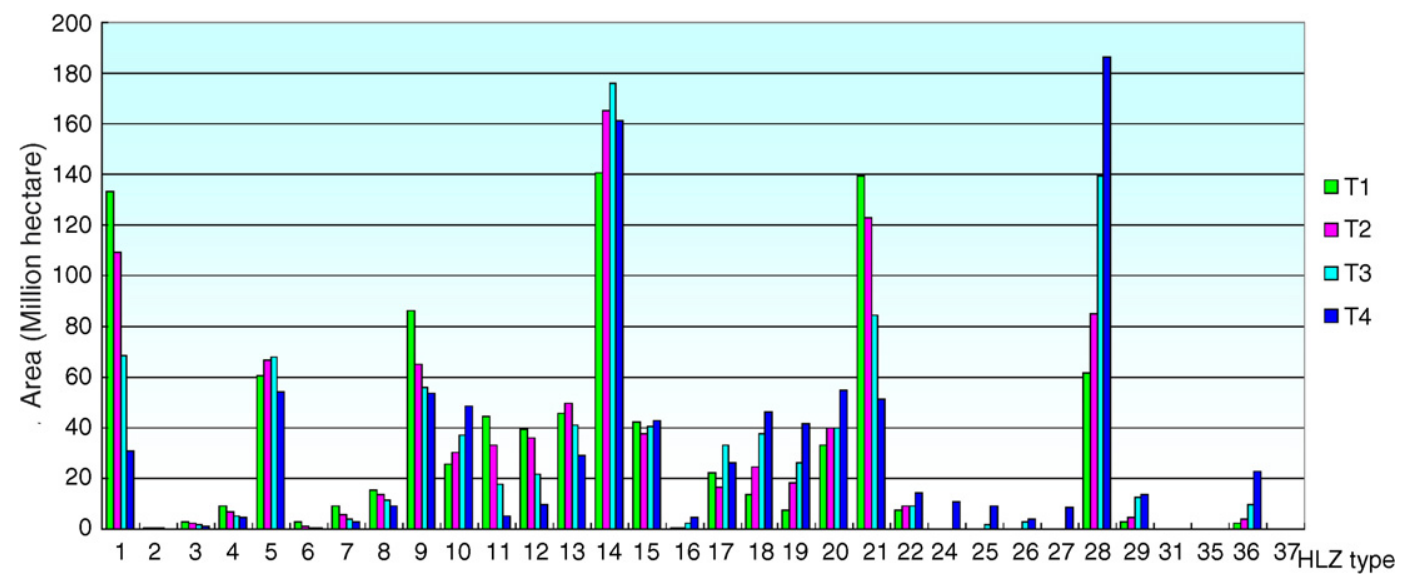

Fig. 7 - Area change of each Holdridge Life Zone type predicted by HadCM3 for the periods 1961-1990 (T1), 2010-2039 (T2), 2040-2069 (T3) and 2070-2099 (T4). 
Table 7 - Area (million ha) change of each Holdridge Life Zone type predicted by HadCM3

\begin{tabular}{|c|c|c|c|c|c|c|c|}
\hline \multirow[t]{2}{*}{ Code } & \multirow[t]{2}{*}{ HLZ type (name) } & \multicolumn{2}{|c|}{ From $\mathrm{T} 1$ to $\mathrm{T} 2$} & \multicolumn{2}{|c|}{ From $\mathrm{T} 2$ to $\mathrm{T} 3$} & \multicolumn{2}{|c|}{ From T3 to T4 } \\
\hline & & $\begin{array}{c}\text { Increase in } \\
\text { area }\end{array}$ & $\begin{array}{c}\text { Rate of } \\
\text { increase (\%) }\end{array}$ & $\begin{array}{c}\text { Increase in } \\
\text { area }\end{array}$ & $\begin{array}{c}\text { Rate of } \\
\text { increase (\%) }\end{array}$ & $\begin{array}{c}\text { Increase in } \\
\text { area }\end{array}$ & $\begin{array}{c}\text { Rate of } \\
\text { increase (\%) }\end{array}$ \\
\hline 1 & Nival & -24.1013 & -18.0734 & -40.6874 & -37.2421 & -37.8093 & -55.1447 \\
\hline 2 & Alpine dry tundra & -0.0481 & -11.7292 & -0.0593 & -16.3959 & -0.1326 & -43.8149 \\
\hline 3 & Alpine moist tundra & -0.7893 & -28.1312 & -0.5005 & -24.8210 & -0.4761 & -31.4013 \\
\hline 4 & Alpine wet tundra & -2.0570 & -22.5020 & -1.9728 & -27.8476 & -0.6476 & -12.6693 \\
\hline 5 & Alpine rain tundra & 6.3056 & 10.4270 & 1.1426 & 1.7109 & -13.6447 & -20.0887 \\
\hline 6 & Boreal desert & -1.5984 & -53.1889 & -0.5668 & -40.2881 & -0.2129 & -25.3425 \\
\hline 7 & Boreal dry scrub & -3.2686 & -36.6020 & -1.8790 & -33.1886 & -0.9647 & -25.5050 \\
\hline 8 & Boreal moist forest & -1.7880 & -11.4991 & -2.3744 & -17.2545 & -2.2848 & -20.0658 \\
\hline 9 & Boreal wet forest & -21.2764 & -24.6502 & -9.1624 & -14.0881 & -2.1153 & -3.7858 \\
\hline 10 & Boreal rain forest & 4.2676 & 16.4323 & 6.8039 & 22.5010 & 11.7859 & 31.8174 \\
\hline 11 & Cool temperate desert & -11.7221 & -26.1914 & -15.0720 & -45.6267 & -12.7331 & -70.8914 \\
\hline 12 & Cool temperate scrub & -3.1480 & -8.0121 & -14.3214 & -39.6249 & -12.0705 & -55.3156 \\
\hline 13 & Cool temperate steppe & 4.1092 & 9.0271 & -8.3729 & -16.8706 & -11.9841 & -29.0471 \\
\hline 14 & Cool temperate moist forest & 24.7717 & 17.6325 & 10.8592 & 6.5709 & -14.7002 & -8.3467 \\
\hline 15 & Cool temperate wet forest & -4.7716 & -11.2870 & 3.1687 & 8.4490 & 2.2157 & 5.4477 \\
\hline 16 & Cool temperate rain forest & 0.4646 & 123.2441 & 1.4430 & 171.4528 & 2.2103 & 96.7429 \\
\hline 17 & Warm temperate desert & -5.8650 & -26.2231 & 16.4667 & 99.7936 & -6.5882 & -19.9840 \\
\hline 18 & Warm temperate desert scrub & 10.8451 & 78.5071 & 12.8568 & 52.1379 & 8.8889 & 23.6935 \\
\hline 19 & Warm temperate thorn steppe & 10.7048 & 146.2401 & 8.4760 & 47.0243 & 14.9467 & 56.4008 \\
\hline 20 & Warm temperate dry forest & 6.8213 & 20.6196 & 0.0033 & 0.0083 & 14.8289 & 37.1598 \\
\hline 21 & Warm temperate moist forest & -16.5191 & -11.8592 & -38.0873 & -31.0222 & -33.2858 & -39.3044 \\
\hline 22 & Warm temperate wet forest & 1.5478 & 20.2485 & -0.2449 & -2.6641 & 5.2775 & 58.9878 \\
\hline 24 & Subtropical desert & & & 0.1000 & & 10.7677 & 10767.7306 \\
\hline 25 & Subtropical desert scrub & & & 1.9300 & & 7.2979 & 378.1307 \\
\hline 26 & Subtropical thorn woodland & & & 2.8800 & & 1.1400 & 39.5835 \\
\hline 27 & Subtropical dry forest & -0.0005 & -100.0000 & & & 8.3364 & \\
\hline 28 & Subtropical moist forest & 23.8325 & 38.6926 & 53.8785 & 63.0695 & 47.1345 & 33.8353 \\
\hline 29 & Subtropical wet forest & 1.5058 & 49.7769 & 7.9045 & 174.4548 & 1.1104 & 8.9295 \\
\hline 31 & Tropical desert & -0.0100 & -50.0000 & 0.0600 & 600.0000 & 0.0800 & 114.2857 \\
\hline 35 & Tropical dry forest & 0.0460 & & -0.0107 & -23.3423 & 0.2343 & 665.0298 \\
\hline 36 & Tropical moist forest & 1.7388 & 69.1370 & 5.3350 & 125.4138 & 13.3989 & 139.7329 \\
\hline 37 & Tropical wet forest & 0.0029 & 6.1032 & 0.0027 & 5.3724 & -0.0036 & -6.6411 \\
\hline
\end{tabular}

increases in Qinghai-Xizang Plateau. This would lead to a considerable shift of the mean center of boreal forest towards the southwest.

Results from the operating diversity index and the patch connectivity index for data corresponding to Figs. 2 and 3 show that HLZ diversity and patch connectivity would increase continuously during the four periods. The increase rates of HLZ diversity and patch connectivity according to HadCM2 would be $0.22 \%$ and $0.14 \%$, respectively, per decade on average; the corresponding rates according to HadCM3 would be $0.38 \%$ and $0.42 \%$, respectively, per decade. In short, climate change would have a considerable impact on the spatial pattern of terrestrial ecosystems in China in the 21st century.

\section{Acknowledgements}

This work has been supported by the National Basic Research Priorities Program (2002CB412506) of the Ministry of Science and Technology of the People's Republic of China, and by Project (40371094) of the National Natural Science Foundation of China.

\section{REFEREN C ES}

Collins, M., Tett, S.F.B., Cooper, C., 2001. The internal climate variability of HadCM3, a version of the Hadley Centre coupled model without flux adjustments. Climate Dyn. 17, $61-81$

Cox, P.M., Betts, R.A., Bunton, C.B., Essery, R.L.H., Rowntree, P.R., Smith, J., 1999. The impact of new land surface physics on the GCM simulation of climate and climate sensitivity. Climate Dyn. 15, 183-203.

Giorgi, F., 2002. Variability and trends of sub-continental scale surface climate in the twentieth century. Part II: AOGCM simulations. Climate Dyn. 18, 693-708.

Holdridge, L.R., Grenke, W.C., Hatheway, W.H., Liang, T., Tosi Jr., J.A., 1971. Forest Environments in Tropical Life Zones: A Pilot Study. Pergamon Press, Oxford.

Johns, T.C., Gregory, J.M., Ingram, W.J., Johnson, C.E., Jones, A., Lowe, J.A., Mitchell, J.F.B., Roberts, D.L., Sexton, D.M.H., Stevenson, D.S., Tett, S.F.B., Woodage, M.J., 2003. Anthropogenic climate change for 1860 to 2100 simulated with the HadCM3 model under updated emissions scenarios. Climate Dyn. 20, 583-612.

Mitchell, J.F.B., Johns, T.C., Gregory, J.M., Tett, S.F.B., 1995. Climate response to increasing levels of greenhouse gases and sulphate aerosol. Nature 376, 501-504. 
Yue, T.X., Du, Z.P., 2005. High precision surface modeling: a core module of new generation GIS and CAD. Prog. Nat. Sci. 15, 73-82 (in Chinese).

Yue, T.X., Fan, Z.M., Liu, J.Y., 2005. Changes of major terrestrial ecosystems in China since 1960. Global Planet. Change 48, 287-302.

Yue, T.X., Haber, W., Grossmann, W.D., Kasperidus, H.D., 1998. Towards the satisfying model for biological diversity. Ekologia 17 (Suppl. 1), 129-141.
Yue, T., Liu, J., Jørgensen, S.E., Gao, Z., Zhang, S., Deng, X., 2001. Changes of Holdridge life zone diversity in all of China over a half century. Ecol. Model. 144, 153-162.

Yue, T.X., Liu, J.Y., Jørgensen, S.E., Ye, Q.H., 2003. Landscape change detection of the newly created wetland in Yellow River Delta. Ecol. Model. 164, 21-31.

Yue, T.X., Xu, B., Liu, J.Y., 2004. A patch connectivity index and its change on a newly born wetland at the Yellow River Delta. Int. J. Remote Sensing 25, 4617-4628. 